\title{
THE DEVELOPMENT OF SPORTS, RECREATION AND ADVENTURE TOURISM IN TOURIST-GEOGRAPHICAL REGIONS OF BOSNIA AND HERZEGOVINA
}

\author{
Aida Bidžan ${ }^{1}$ \\ Haris Gekić
}

\begin{abstract}
Sports, recreation and adventure tourism are activities that relax tourists and put them away from everyday stress situations, and it all takes place through swimming, hiking, relaxing in nature, altitude residence, paragliding, rock climbing, rafting, cycling tours, golf, tennis, aqua aerobics, volleyball, skiing, etc. Natural and anthropogenic tourist potentials which exist in the $\mathrm{BiH}$ tourism and geographic regions are suitable for the development of these specific forms of tourism. Sports events are unavoidable side effects in the development of these forms of tourism. Entertainment - recreational tourist regional offer, in a broader sense, includes an offer that is used to meet all other needs of tourists, participants and organizers of such events. Moreover, sports, recreation and adventure programs, which are implemented as an integral part of tourism offer of the tourist-geographical regions, are certainly renting and using various sports facilities and equipment, schools of various sports skills, sports games, tournaments and contests followed by sports-entertainment attractions, which certainly lead to job creation and employment of professional staff and young population structure. It is necessary to ensure available public space for a part of these activities, then equipped sports and recreational fields or recreational sports equipment and halls for other activities, which also makes room for employment in $\mathrm{BiH}$ regions in which it is wanted to develop these specific forms of tourism.

The aim of this study is to determine the possibilities for development of sports, recreation and adventure tourism in $\mathrm{BiH}$ tourist-geographical regions followed by their diversity and classification with respect to which natural-geographical tourist attractions will be developed. The priorities and problems of their tourist valorisation will be determined, as well as the way they are promoted among both foreign and domestic tourists. In this study, noticable are the following touristgeographical methods: analysis, synthesis, causal methods, classification, tourist valorization, field research and mapping methods.
\end{abstract}

Key words: sports tourism, entertainment, recreation, potentials

\section{INTRODUCTION}

The modern tourist understanding of each tourist is globalism and using every free moment for finding new contents, release of adrenaline and new experiences. This changes the previous stationary mass tourism where tourists were offered the sea, sun and sand. In this respect, there are alternative types of tourism which cease to be mass, where tourists as individuals or small groups aspire to and take place in the intact nature where they can be engaged in sports activities and spend their long-awaited vacation in a dynamic way.

\footnotetext{
${ }^{1}$ Department of Geography, Faculty of Science, University of Sarajevo, Zmaja od Bosne 33 - 35, 71000 Sarajevo, aidabidzan@gmail.com

${ }^{2}$ Department of Geography, Faculty of Science, University of Sarajevo, Zmaja od Bosne 33 - 35, 71000 Sarajevo, hgekic@gmail.com
} 
The subject of this paper are opportunities for development of sports and recreation and adventure tourism in terms of the existing tourism supply and demand in the world and consequently in the national environment. In many societies, the higher reaches of personal mobility remain the exclusive domain of the privileged (Hall, 2004). Similarly, participation in many sport and recreational pursuits is rigidly defined by social class, race and gender (Gibson, 2005).

To develop sports and recreation and adventure tourism as efficiently as possible in an area, it is necessary that these areas have the following factors: intact natural environment, customer service, organized transport, facilities and sites, organized entertainment, accommodation of different categories, hereditary involvement in sports, built superstructure and a good organizer of these specific forms of tourism. These forms of tourism can be of different levels, namely: international, national, regional or local character, which depends on their organization and marketing. Sport and tourism are the mass social and economic phenomena which are in many ways interlinked. This relationship is reflected through: factors of tourism and sports, functions that generate tourism and sport, as well as their economic effects. Although sport in tourism occurs in various forms, a dominant role in modern tourism has "sport for all", which in our terminology can be identified with sports recreation. Sports recreation with numerous attractions is the main lever of active holidays in tourism industry. New tendencies in the development of tourism show that changes in tourism trends are replacing traditional motives of holiday with the motives and content of active holidays. As adventure sport and sports recreation are the key motives and content of active holidays, their development affects the content and quality of active holidays in tourism. The aim of this paper is to show the possibilities of development and improvement of the quality of sports and recreation and adventure tourism, as well as tourism in general in the tourist-geographical regions of Bosnia and Herzegovina $(\mathrm{BH})$.

Sports and recreation and adventure tourism are all those forms of active or passive involvement in sports activities on an individual or organized basis in commercial or noncommercial purposes, which cause travel outside the usual places of residence, and it is a form of tourism trends in which sport is the main motivation for travel (Kesar, 2011). Moreover, sports and recreation and adventure tourism can be defined as "tourism in which sport is the main motive for travel and accommodation for tourists in a tourist destination" (Bartoluci, 2003). Sport and tourism are complex and dynamic phenomena that have in recent decades beenengaged in an expanding interplay of mutual interests at a range of spatial and temporal scales. Sport is constantly in a state of change, subject to socioeconomic forces, innovation and experimentation (Higham \& Hinch, 2009).

These specific forms of tourism are activities that relax tourists and move them away from everyday stress situations, and it is realised through swimming, hiking, relaxing in nature, visiting high-altitude area, diving with special equipment, paragliding, rock climbing, 
rafting, cycling tours, golf, tennis, aquaerobic, volleyball, skiing, skating, etc. For sports and recreational, and adventure tourism activities, certain preconditions are necessary, such as the following tourist potentials: natural, anthropogenic, financial, information, knowledge, etc.

Adventure tourism distinguishes itself from normal tourism on five counts. Firstly, there is a degree of readiness or preparedness on the part of the individual. This involves certifications, trip planning and the organising of skilled personnel to undertake the adventure. Secondly, adventure tourism is more expensive because of the costs surrounding the training and renting or buying of equipment. The third distinction is that adventure tourism requires planning when entering remote areas that are not usually visited by the average tourist. Fourthly, an adventure activity, such as skiing on a mountain or surfing on the beach, depends on seasonal weather cycles. Fifthly, the professional adventure tour suppliers are required to employ experienced and certified adventure guides (Swartbrooke, et al., 2003).

According to Cashmore (2002), most people think of adventure as an adrenaline rush and that the followers thereof are driven by a death wish. According to Standeven (1999), adventure activities indicate a "quest for excitement" and they provide an opportunity to produce pleasurable forms of tension and excitement, which offer an important counterbalance to the routines of daily life in modern society. Whiles interacting with the environment, participants engage in hiking, rafting, kayaking, mountain biking and many more. There is a growing trend towards adventureorientated holiday behaviour in people seeking a more intensive recreational experience (George, 2004; Hudson, 2003).

\section{SPORTS, RECREATION AND ADVENTURE TOURISM WITHIN NATURAL TOURIST POTENTIALS IN TOURIST-GEOGRAPHICAL REGIONS OF BOSNIA AND HERZEGOVINA}

Bosnia and Herzegovina has valuable tourism potentials and sports facilities. First of all, there is a rich cultural and historical heritage, natural attractions, especially mountains and favourable climate, as well as the proximity to major European generating center, which in general contributed to the recognition of Bosnia and Herzegovina as a tourist destination. All natural and geographical areas where tourists can engage in sports, recreational and adventure activities belong to the sporting potentials in tourism. The following table 1 will show natural tourist potentials and forms of sports and recreational activities that can be performed on them. 
Table 1: Natural tourism potentials and forms of sports, recreation and adventure tourism

\begin{tabular}{|l|l|}
\hline \multicolumn{1}{|c|}{ Natural tourism potentials } & \multicolumn{1}{c|}{$\begin{array}{c}\text { Forms of sports, recreation and adventure } \\
\text { tourism }\end{array}$} \\
\hline Mountains & $\begin{array}{l}\text { hunting, mountain biking, hiking, skiing, } \\
\text { boarding, paragliding, mountaineeiring etc. }\end{array}$ \\
\hline Sea & Swimming, sailing, surfing, fishing, diving \\
\hline Lakes & rowing, swimming, fishing \\
\hline Rivers & fishing, rafting, swimming, kayaking \\
\hline Forest & orienteering etc. \\
\hline
\end{tabular}

Source: compiled by authors

The development of sports and recreational tourism in Bosnia and Herzegovina started on the basis of health tourism based on particularly favourable healing natural potentials of thermal and mineral springs. The tradition of spa tourism is more than 130 years old and it started in the areas of climate and health centers primarily to protect and improve health, rehabilitation, and treatment with the help of natural factors. The Romans opened most of the spas in the area of Bosnia and Herzegovina.

Table 2: Sports, recreation and adventure tourism on natural tourist potentials in touristgeographical regions of Bosnia and Herzegovina

\begin{tabular}{|c|c|c|}
\hline \multirow{2}{*}{$\begin{array}{l}\text { Tourist- } \\
\text { geographical } \\
\text { region }\end{array}$} & \multicolumn{2}{|c|}{ Natural Tourism Potentials } \\
\hline & Sports and recreational tourism & Adventure tourism \\
\hline Sarajevo & $\begin{array}{l}\text { Igman, Bjelašnica, Trebević, Great alley, } \\
\text { Vilsonovo alley, Dariva, Crnoriječka } \\
\text { plateau, Well of Bosna }\end{array}$ & $\begin{array}{l}\text { Treskavica, Bjelašnica, } \\
\text { Visočica, Crnoriječka plateau, } \\
\text { canyon Miljacke }\end{array}$ \\
\hline Mostar & $\begin{array}{l}\text { Vran, Raduša, Prenj, Velež, Čvrsnica, } \\
\text { Neretva, Trebižat, Bregava, }\end{array}$ & $\begin{array}{l}\text { Canyon of Neretva, Diva } \\
\text { Grabovica, canyon of } \\
\text { Rakitnica, }\end{array}$ \\
\hline Banja Luka & $\begin{array}{l}\text { Kozara, Vlašić, Čemernica, Lisina, } \\
\text { Motajica, Uzlomac, Vrbas, Sana, Balkana }\end{array}$ & $\begin{array}{l}\text { canyon Tijesno, Zvečajska } \\
\text { glen, glen of Crna rijeka, } \\
\text { Kozara, Vlašić etc. }\end{array}$ \\
\hline Bihać & $\begin{array}{l}\text { Grmeč, Plješevica, Lanište, Klekovica, Una, } \\
\text { Sana }\end{array}$ & Una, Sana, Plješevica \\
\hline Tuzla & Konjuh, Majevica, Ozren, Javornik & Konjuh \\
\hline Podrinje & $\begin{array}{l}\text { Jahorina, Zelengora, Sutjeska, Javor, Drina, } \\
\text { Ćehotina }\end{array}$ & $\begin{array}{l}\text { Jahorina, Zelengora, Volujak, } \\
\text { Drina }\end{array}$ \\
\hline Posavina & Drina, Sava & Drina, Sava \\
\hline Doboj & Ozren, Trebava, Motajica, Zvijezda & \\
\hline East Herzegovina & $\begin{array}{l}\text { Bregava, Trebišnjica, Hutovo blato, lakes: } \\
\text { Alagovac, Bilećko, Klinje }\end{array}$ & Zelengora, Volujak, Maglić \\
\hline $\begin{array}{l}\text { South West } \\
\text { Bosnia }\end{array}$ & $\begin{array}{l}\text { Šator, Dinara, Kamešnica, Vran, Livanjsko i } \\
\text { Kupreško polje }\end{array}$ & $\begin{array}{l}\text { Šator, Kamešnica, Vran, } \\
\text { Livanjsko i Kupreško polje }\end{array}$ \\
\hline Maritime & Neum-Klek bay & Neum-Klek bay \\
\hline $\begin{array}{l}\text { West } \\
\text { Herzegovina }\end{array}$ & $\begin{array}{l}\text { Čvrsnica, Čabulja, Trebižat, Nature Park } \\
\text { Blidinje }\end{array}$ & Čvrsnica, Čabulja \\
\hline Travnik & Vranica, Bitovnja, Raduša, Rostovo, Vlašić & $\begin{array}{l}\text { Vranica, Bitovnja, Raduša, } \\
\text { Rostovo, Vlašić }\end{array}$ \\
\hline
\end{tabular}

Source: Bidžan, 2011 
As we can see from Table 2, Bosnia and Herzegovina as well as its tourist-geographical regions are rich in natural tourism potentials, both geomorphological and hydrographic where various forms of sports and recreation and adventure tourism can be developed. Generally, Bosnian tourism lacks proper functioning tourist development of space in the immediate and wider environment of tourism and catering facilities, which must be resolved quickly if one seriously wants to start the development of these forms of tourism.

Further, we should note that an average altitude of Bosnia and Herzegovina is about 693 $\mathrm{m}$. More than $4 / 5(85.8 \%)$ of the territory of our country has an altitude over $200 \mathrm{~m}$. The highest peak is Maglić, $2386 \mathrm{~m}$, and more than 30 peaks have an altitude of more than $1,700 \mathrm{~m}$.

So that, thanks to these natural resources, the tourism on Bosnian and Herzegovinian mountains can include a wide array of activities for tourists of various sporting preferences from hikers and climbers to speleologists, but they all have in common a love of nature and spending time in the fresh air. The tradition of hiking, mountain climbing and skiing in our region exists over a hundred years, as evidenced by numerous documents and objects. The expansion of sports and recreational tourism started after the XIV Winter Olympic Games in Sarajevo, in 1984. Mountains Bjelašnica, Igman, Jahorina and Trebević were ready for Alpine and Nordic skiing as well as ski jumps and bobsled. We will give a description of tourist activities on the two most important Bosnian and Herzegovinian mountains: Igman and Bjelašnica.

On Igman, on Veliko polje (Big Field), there is a $30 \mathrm{~km}$ long track for Nordic crosscountry skiing and biathlon, while on Malo polje (Small field), there are ramps of 90 and $70 \mathrm{~m}$ which were destroyed in the war, but the Sarajevo Canton Government is planning to renew them soon. Igman and Bjelašnica together form the ski complex which is a unique space, even in the world scale. Namely, it is said that there does not exist a combination of sharp slopes for alpine ski disciplines and wide expanses like here, and only a few kilometers away the tracks for those who enjoy cross-country skiing. Moreover, for visitors in summer, Veliko polje offers two football fields, a universal sports court for basketball, handball and volleyball, as well as four tennis courts, then tracks for walking and biking, special courts for grilling with wooden benches and tables. Moreover, on Malo polje there is a universal football and volleyball court. As for accommodation, this mountain has 105 beds, which is not enough if one wants to seriously develop tourism (http: // www. zoi84.ba/stranica/ski-centar, www.bhtourism.ba/Turist_br26. pdf).

In addition to Igman, Bjelašnica is an extremely popular tourist destination for hiking and skiing. The main zone has a few facilities from the time of the Winter Olympic Games, including hotels and ski resorts. Besides the classic Alpine ski disciplines, paragliding, for which conditions are excellent, has been becoming increasingly popular in recent years. Bjelašnica has 8,345 $\mathrm{m}$ of ski trails for all alpine disciplines. The quality of the tracks is still current. As the paths are illuminated, night skiing is also possible on them. During the 
summer season, the following is available to tourists: hiking, mountain bikeing, party organizing, eco-fairs, playing tennis in a completely natural setting, organizing mini football, volleyball and other tournaments, as well as many other services. For nature lovers, there can also be organized excursions to Bjelašnica with the possibility of riding the cable car up to the top of Bjelašnica, and touring of the surrounding villages.

In 2015 in the winter ski season which lasted 112 days, according to the organizers of slopes, Igman and Bjelašnica were visited by a record number of 300,000 visitorsž; in addition to domestic tourists, most tourists came from Croatia, Montenegro, Serbia, Germany, Austria and Slovenia. Experts say that for the tourism trends best suited are mountains of medium height, and it is beneficial that they affect almost one quarter (24.3\%) of the BH space. We particularly refer to the convenience for winter sports which, as a rule, provides subalpine relief. Northwestern and northeastern slopes of the mountains of altitudes above 1,000 or $1,100 \mathrm{~m}$, as well as the southwestern and southeastern slopes above altitudes of 1,400 and $1,500 \mathrm{~m}$ have a large number of days with the required thickness of snow cover for winter-sports tourism.

The mountains of Bosnia and Herzegovina are among its most attractive natural tourism potentials ${ }^{1}$, and this is especially true for the mountains in Sarajevo, Travnik and southwestern Bosnia region. They have miles of ski trails for all alpine disciplines where the difference in altitude from the top to the finish goes even over 1,000 $\mathrm{m}$ on some of the mountains. Staying on Bosnian-Herzegovinian mountains is interesting at any time of year, especially in winter due to the outstanding sports and recreational conditions. Vast pastures covered with snow are excellent facilities for skiing and sledding in the winter, and in summer it is just a feast for the eyes to all visitors, which provides a range of opportunities for some sports, such as mountain biking, paragliding, hiking, climbing, indoor soccer, and the like. Further, it must be noted that the tourist-geographical position of the mountains compared to densely populated and economically developed areas, especially cities, is very important, and the following example shows it. Namely, the increase in tourist recreational role of the mountains (Bjelašnica, Igman and Jahorina) near Sarajevo strongly contributes to their good position in relation to the Sarajevo-Zenica basin, the most densely populated and economically most developed basin of Bosnia and Herzegovina. Moreover, a favorable tourist and geographical position in relation to urban areas have Vlašić (Travnik, Zenica, Jajce), Čajuša and Stožer (Kupres, Bugojno, Jajce and Split), Ravno Rostovo (Bugojno and Novi Travnik), Lisina (Mrkonjić Grad, Šipovo, Jajce), Kozara (Prijedor, Banja Luka, Bosanski Novi), etc.

In recent years, accommodation capacities and infrastructure have been built on many mountains of Bosnia and Herzegovina, as well as tourist facilities for many sports,

\footnotetext{
${ }^{1}$ This refers to the largest number of mountains in the country, while a smaller number on their entire surface is arid, barren, and it reduces their tourist attraction (eg. some mountains in Herzegovina).
} 
particularly those related to snow, tourist propaganda is increased and the like, which should contribute to an increase in tourist traffic in the mountainous areas of the country. Among natural tourism resources, very attractive are both gorges and canyons of the following rivers: the Drina, Vrbas, Una and Neretva rivers and their tributaries, and they are among the better known and larger geomorphological tourism potentials of this kind in Bosnia and Herzegovina. Important Bosnian-Herzegovinian roads lead along these tourism potentials which increases the possibility of its tourist valorization, especially the increase of the opportunities for adventure tourism.

In addition to geomorphological tourism potentials for the development of sports and recreation and adventure tourism, an important role is played by hydrographic tourist potentials. Small but significant coast of Bosnia and Herzegovina, as a part of the Mediterranean and European and world tourist value together with thermo-mineral springs, among which were created spa tourist spots, and lakes, some rivers and tourist attractive waterfalls and river springs, make major hydrographic motives of Bosnia and Herzegovina.

An integral part of tourist attractions of hydrographic motives of Bosnia and Herzegovina are their aesthetic and rare elements, as well as the enrichment of the landscape. Our country has a very short coastline, then lakes that do not have a large surface area, and with the exception of the Sava River, other short rivers that are partially have fast flow and variable flow during a year. These rivers have a specific significance for tourism development. Here, first of all, it is refered to rafting on the Drina, Neretva, Una and Vrbas.

Our little coastline located in the Gulf of Neum-Klek, which belongs to the coastal touristgeographical region, has an area of $8 \mathrm{~km}^{2}$, width $1-1.3$ kilometers, and length of $6.2 \mathrm{~km}$ (Čehajić, J., 1987). Coasts and coastallines in tourism are undoubtedly the most complex and most stable tourist potentials, and coastal tourism in our country is of great importance. The duration of the swimming season after considering all the parameters that affect it in Neum, is limited by the average daily temperature of sea water above $18^{\circ} \mathrm{C}$. When the average daily air temperature and sea water above $18^{\circ} \mathrm{C}$ are taken as limiting values of the beginning and end of the bathing season, it can safely be argued that the bathing season is not limited to the summer period. Hydroclimatic opportunities in Neum represent the potential for the development of bathing tourism even during the spring or autumn season. Date of the tourist season in Neum is on May 19, after which, on average, there are not daily temperatures of the sea water below $18^{\circ} \mathrm{C}$. The end of the tourist season is determined by October 10, after which there is the expected emergence of an average daily temperature below $18^{\circ} \mathrm{C}$, and therefore the swimming season lasts for 144 days, or almost five months. Thanks to all these specific attractive hydroclimatic complexes of warm sea coast and the sea, in this area it is possible to develop the following types of sports and recreational and adventure forms of tourism: bathing and recreation, cruising, surfing, sport fishing, diving and the like. However, the dominant form of tourism in Neum 
was presented almost entirely by bathing tourism, with a day trips or longer stay of tourists in a hotel or private accommodation, oriented to narrow terraces, which are defined by the beaches beneath the town of Neum.

Out of hydrografic tourism potentials, we need to mention the lakes. Being natural or artificial, they have the emphasized recreational properties of attractiveness. As such, they are the basis for the development of bathing, fishing, stationary, excursion, youth, sports and manifestation tourism. Their role is higher in domestic than in foreign tourist trends. It is known that a real tourist attraction are only not devastated lakes. Natural lakes of Bosnia and Herzegovina, and within that mostly mountain, as most artificial water accumulations have uncontaminated water. These lakes are suitable for swimming and other sports recreation activities on the water.

High water temperatures and good insolation of some lakes in $\mathrm{BH}$ provide favorable conditions for bathing and swimming. Thus, for instance, in the Mostar touristgeographical region on Boračko Lake, the water temperature at the surface is $18-22^{\circ} \mathrm{C}$ for 3 - 4 months (sometimes reaches up to $28^{\circ} \mathrm{C}$ ), which makes it equated with the largest and most attractive tourist lakes in Macedonia, and in the Travnik tourist-geographical region on Veliko jezero (Big Lake) on the river Pliva, in August, the warmest month, it is $17,9^{\circ} \mathrm{C}$ although, often in very hot summer days it reaches $20^{\circ} \mathrm{C}$. These lakes also have the optimum depth for swimming, as the average depth of Veliko jezero is $18.3 \mathrm{~m}$ and Boračko Lake is $10.3 \mathrm{~m}$, while the maximum depth in Veliko jezero is $36.2 \mathrm{~m}$, and in Boračko Lake is $13.8 \mathrm{~m}$. Certainly, it need to be pointed out that Bosnia and Herzegovina is rich in rivers. Our rivers are of a large and multifaceted significance. Tourist attraction of the rivers of Bosnia and Herzegovina is based on their convenience for recreation through swimming, water sports, fishing and more. To the group of the rivers of independent tourism potentials in our country we need to include the Drina with Sutjeska, Una with Unac and Sana, Vrbas and Pliva with Janje and the Neretva, which are very suitable for adventure tours like rafting, kayaking and so on.

The mountain river Neretva, which is located in the Mostar tourist-geographical region, in the upper part of its water stream, in the canyon upstream from Konjic, provides a unique experience for adrenaline-filled rafters. Track length for rafting on the Neretva from Glavatičevo to Konjic is about $23 \mathrm{~km}$ and takes about 5 hours with the beautiful canyon and waterfalls, which can be seen on the descent. Part of the flow from Glavatičevo to Bjelimići is a kind of an air spa which is very well visited throughout the year. The opening of the fishing season on the Neretva River is in April and it closes in November of the current year. As it is rich in fish, it is quite visited by anglers from all over Bosnia and Herzegovina. In the lower part of the rafting route in the village Džajići $4 \mathrm{~km}$ from Konjic, there is a beach that is visited during the summer season. While sailing on the Neretva rafters can enjoy the beauty of the Mali and Veliki Canyon with unspoiled nature and scenes that are not visible from the road, as well as in four adrenaline rapids which are 
arranged so that each subsequent is more extreme than the previous one. Skippers who run the boats are trained professionals and will certainly take the crew from start to finish. Twenty odd agencies do rafting on the Neretva. For those looking for more adrenaline, the right time for rafting are April and May with high water levels of the Neretva.

Especially attractive tourist product of the Podrinje tourist and geographical region is rafting $^{1}$ down the Drina. Holiday packages can be of one or more days with the possibility of rest and recreation next to the river. From Ustikolina to Goražde tourists will enjoy the hidden beauty, unspoiled nature and an unforgettable adventure. This river and its tributaries: Prača, Kolina, Kosovska river are abundant in a variety of fish species and are a real pleasure for fishermen. The Drina river with its cold, clear and greenish water is suitable for sports and recreation and adventure tourism (swimming, rafting, white water rafting or fishing). On the banks of the Drina River there are pedestrian zones, city beaches, as well as volleyball and football on the sand in larger cities. On the river itself or on the coast, numerous events are held such as Zvornik regattas and "Zvorničko ljeto"Zvornik (Zvornik summer), then Drina - Prača rafting and "Internacionalni festival prijateljstva"- Goražde (international festival of friendship), Drina Regatta and jumps from the Višegrad bridge - Višegrad, etc. Hydroelectric power plants Višegrad, Peručac and Zvornik halted to some extent the strength of the Drina River, turning it into usable energy for people, but at the same time creating beautiful artificial lakes, suitable for sports and recreation and adventure tourism.

In the Bihać tourism geographical region, the Una river by many is the most beautiful river in the whole country, dear to heart of all communities which formed, in the course of history, along $207 \mathrm{~km}$ of its flow. The Una is to Krajina what the Neretva is to Herzegovina - life, and the life force of the Una is respected throughout the history of this tourist and geographical region. Štrbački buk and the Veliki kanjon (Grand canyon), the most beautiful parts of the river, can be detected only by kayak, canoe or raft. The first big waterfall of its river flow is near Martin Brod, a village located on the bottom of the canyon, where the Unac river flows into the Una. In this very part, the Una is the most breathtaking because tuff created a multitude of channels, rapids and islands, as well as several major waterfalls of which the greatest height is approximately 55 meters. Those natural waterfalls represent a unique value which for decades successfully attracts lovers of natural beauty to the Una, but also fishermen and artists which are seeking for the inspiration for their works in the Una.

Traditionally, the Una Regatta (international tourist kayak race) is held at Martin Brod, which was interrupted at the beginning of the nineties, but after the war it has been reestablished again. Martin Brod is known throughout Europe for its rafting, sport favored by restless water of the river Una that is full of rapids, so that each year it attracts a large

\footnotetext{
${ }^{1}$ Raft is the unusual vessel built of wooden logs capacity of about 15 people, lasts one day, with the possibility of fishing from the raft and enjoying the gastronomic offer of local specialties.
} 
number of athletes throughout Europe. International Tourist Una regatta lasts for seven days and usually takes place in July. The regatta's route is as follows: "Kulen Vakuf" camp in the municipality of Bihać - Štrbački buk - Bihać - Ostrožac the Uni / Cazin - Bosanska Krupa - Novi Grad - Hrvatska Kostajnica (the Republic of Croatia). This river is ideal for the development of sports and recreation and adventure tourism.

Moreover, another river worth mentioning is the Vrbas River which flows through two tourist-geographical regions: Travnik and Banja Luka. The main left tributaries of the Vrbas are the Pliva, Crna rijeka (Black River) and Krupa, and the main right tributaries are the Bistrica and Ugar which are in addition to thier main rivers suitable for the development of some forms of sports and recreational tourism. On it each year is held "Ljeto na Vrbasu" (summer on the Vrbas) in Banja Luka where the main activities are races of dayak and kayak racing boats, diving from the town bridge, rafting regatta, swimming across the river Vrbas, beach volleyball, football, basketball, sports fishermen competition, parachute jumping, promotion activities of sports clubs and others.

This traditional event is held in the second half of July with an aim of promoting and protecting the river Vrbas, and enriching the tourist offer of the town. The central events are taking place on the beach "Zelena" below the walls of the fortress Kastel. The event each year gathers a large number of artists, athletes, entertainers and other Banja Luka associations and individuals whose activities on the Vrbas and its banks prepare a rich cultural, entertaining and sports program. The event every year attracts an increasing number of participants, visitors and media that in this way point to the importance of the Vrbas River for the city of Banja Luka and its citizens and beyond. This river is ideal for the development of sports and recreation and adventure tourism,too.

As for the biogeographical tourism potential, it certainly contributes to the development of various sports and recreational and adventure forms of tourism, such as hunting, fishing, photo safaris, sports manifestations etc, and thus they must be adequately valorized. Biogeographical tourism potentials can be independent and complementary. They are more pronounced as complementary tourist potentials while complementing the attractiveness of other natural and anthropogenic tourist potentials. For instance, forest areas rich in wildlife, meadows, fish-rich waters and so enrich the tourist offer of the observed regions. Among independent biogeographical tourist potentials are protected natural areas, and among them the most attractive national parks: Sutjeska, Kozara, Una which enable operation of various forms of sports and recreation and adventure tourism without compromising the parks. Besides, nature and hunting reserves are important for the tourist movements, as well as larger areas of forest near densely populated cities, which enable recreation for the local population (Fig.1.). 


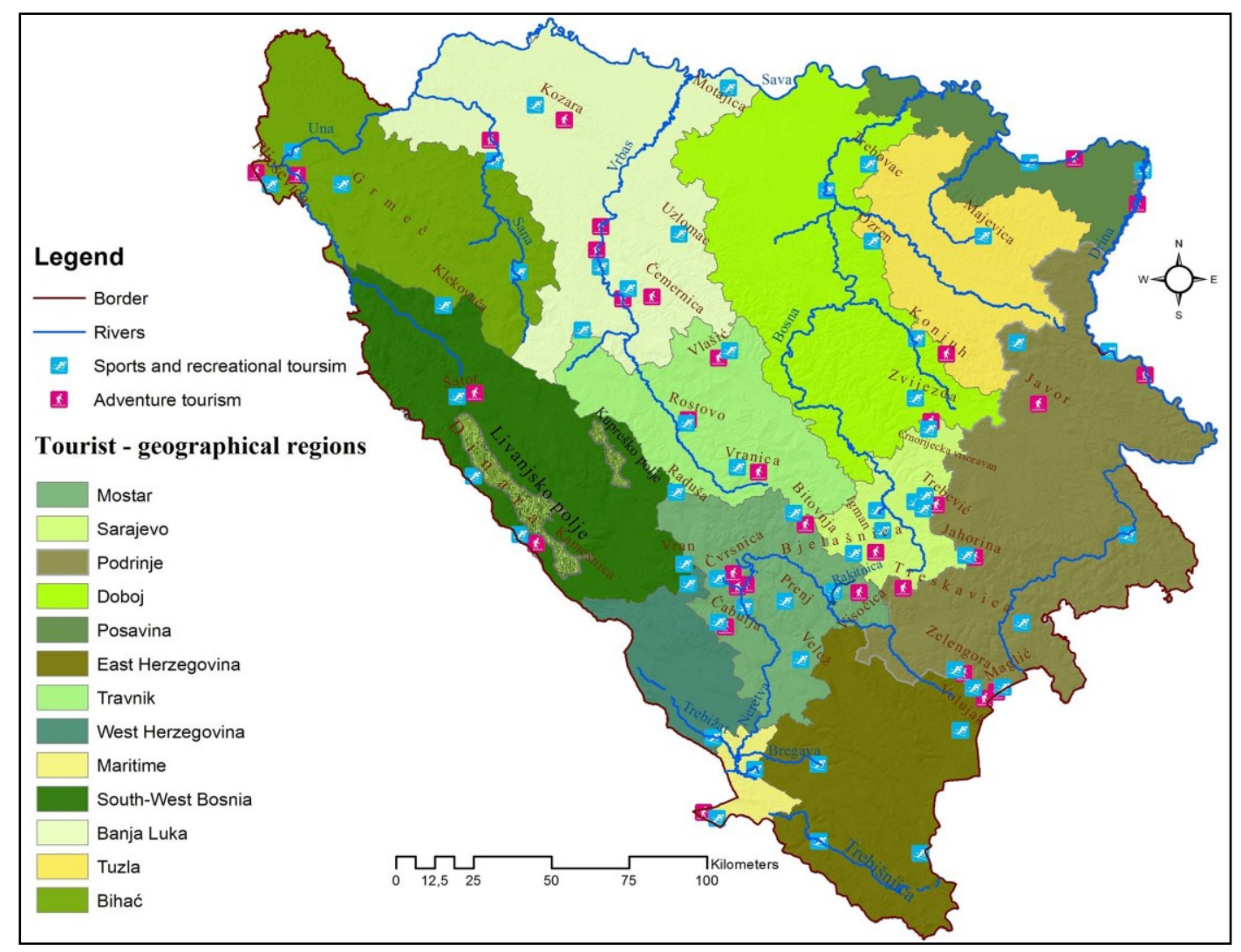

Fig.1. Sports, recreational and adventure tourism in tourist-geographical regions of Bosnia and Herzegovina

The diverse habitats throughout the country made up of lowland, mountain, karst, wetlands areas along rivers and lakes and plateau regions and rich flora and fauna are excellent preconditions for the development of tourism. The rich habitats are inhabited by various types of wildlife for hunting, that are attractive, big as well as small game, such as: deer, fallow deer, roe deer, chamois, ibex, mouflon, wild boar, bear, wolf, wood grouse (western capercaillie), stone marten or white breasted marten, European pine marten, hare, hazel grouse, pheasant, rock partridge, grey partridge, quail, woodcock, wild geese, wild duck, fox, wild cat, badger ...

The tradition of hunting tourism in the territory of Bosnia and Herzegovina exists from the Austro-Hungarian rule, only to take on unsustainable trends and directions in the last 50 years of the last century. Hunting associations, especially separate hunting areas and revirs should be concerned with the organization of hunting and hunting-tourist offer of Bosnia and Herzegovina. The best hunting tourism offer are in the hunting grounds of the following areas: Travnik, Podrinje, east Herzegovinia, Posavina, Bihać and Banja Luka tourist and geographical regions (Bugojno, Zavidovići, Romania, Bijele Vode, Zelengora, etc.). 
In addition to hunting, Bosnia and Herzegovina has ideal conditions for the development of fishing tourism. Mountain rivers are especially interesting to the lovers of this sport and are characterized by exceptionally pure, transparent water whose temperature is even in the summer period only a few degrees above zero. They are inhabited by the rarest fish species such as grayling, brown trout and Danube salmon, but in the lower parts of these waters common nase, common carp, Danube roach, common barbel which in these areas reach a much larger extent. Type of fishing that specifically binds to these rivers is Fly Fishing. Bosnia and Herzegovina has one of the best revirs in the Balkans and beyond for the implementation of this sport fishing. On this revirs, there are conducted various competitions from clubs to state as well as European and international. Fishing techniques of fly fishing give a special charm and it is made of a special principle which true anglers respect, and it says "catch, kiss and return to the water" and of course do not forget to take a photo. In general, that relationship of fishermen and fish leaves behind the priceless charm and culture of sport in that as many fishermen as possible feel the power and magic of fishing and fly fishing; on the other hand fish stocks remain at a high level that represents a great wealth for sports fishermen. Among the most important revirs in Bosnia and Herzegovina are revirs on the rivers Ribnik, Pliva, Sanica, Una, Unac, Klokot, Sana, Krušnica, Neretva, Uloga, Doljanka, Šuica, Lašva, Dragać, Bregava, Fojnica, and so on.

Anthropogenic tourist resources that are essential for sports and recreation and adventure tourism include purpose-built facilities for professional or amateur sport, and these are: stadiums, arenas, sports - recreational centers, racetracks, tennis courts, outdoor sports grounds, training grounds for exercise, running tracks, and so on. In addition to the rich natural and anthropogenic tourist potentials for the development of these two specific forms of tourism, there should in line with them be organized a number of events which would constantly upgrade them every year. Moreover, for the implementation of sports and recreational tourism there should exist appropriate sports equipment and playgrounds, which would be rented and thus new jobs would be created, which would improve more balanced regional development of Bosnia and Herzegovina. We will mention only some of the sports and recreational programs that should be carried out as an integral part of the tourism offer of a tourist and geographical region, namely: rental of various sports facilities, use of sports facilities and equipment, school of various sports skills, sports games, tournaments and various competitions, sports and entertainment attractions (Bartoluci, 2003).

Integral part of tourism are also sport and recreational programs and events. Due to their diversity and specificity, experts who may well create, organize, and implement such programs must be professionally trained (educated). In doing so, emphasized is the role of sports animators as holders of sports animation programs, since their role is not just about knowledge of sports activities but also all other animation activities and communication with the guests, the requirements placed upon them are quite high. In addition to the specific knowledge and skills of tourism and sports and recreational programs, they must 
possess certain psychological and physical characteristics, talent and sense of contact with the guest, and a certain level of sports education.

\section{CONCLUSION}

Active holiday is a synonym of tourist rest, and it includes sports facilities including a number of activities in attractive natural surroundings. In this context, exploring the needs of a modern man lacking physical activity and contact with nature, who lives too fast stressfully, we come to the conclusion that tourism should achieve a number of objectives that will eventually lead to the recovery and satisfaction. Sports recreation play a dominant role in meeting the needs for movement and proper activity, which is now imperative for a quality vacation. Therefore, it is not unusual for sport and tourism to experience an expansion because of the increasing interest, but also the needs of the increasing number of tourists.

The development of sports and recreation and adventure tourism in Bosnia and Herzegovina would contribute to the economic development of our country through the following factors: new jobs, improvement of infrastructure and suprastructure, increase of consumption, an opportunity to improve the image, cultural exchange and others. Bosnia and Herzegovina has exceptional comparative advantages for the development of different forms of sports and recreation in tourism. This is supported by the trends of modern tourist demand, especially from Western European countries gravitating toward us.

However, for the future of sports and recreation and adventure tourism, it is necessary to innovate obsolete tourist-sports offer by new facilities and content to the modern requirements of the tourist demand. The quality of sports and recreation offer need to be innovated through numerous sports and recreation and adventure programs, which can be successfully programmed and implemented by experts of sports and recreation. Previous experiences in Bosnia and Herzegovina, even in some receptive tourist countries, show that investment in these forms of tourism are the quality and profitable investment.

\section{REFERENCES}

1. Bartoluci, M. (2003). Ekonomika i menedžment sporta. Zagreb: Informator.

2. Bidžan, A. (2011). Turističko-geografsko rejoniranje kao osnova geografske regionalizacije Bosne i Hercegovine, Magistarski rad odbranjen na Prirodnomatematičkom fakultetu Univerziteta u Sarajevu, Sarajevo.

3. Cashomore E (2002). Sport psychology: the key concepts. Routledge Key Guides, Routledge, New York.

4. Dinić, J. (1990).Turistička geografija, Univerzitet u Beogradu Ekonomski fakultet, Beograd.

5. George R (2004) Marketing South African tourism. 2nd edn. Oxford University Press, Cape Town. 
6. Gibson, H. (2005). Towards an Understanding of Why Sport Tourists Do What They Do. In Sport

7. Tourism: Theory and Concepts, (H. Gibson ed.) pp.66-85, London: Routledge.

8. Hall, C.M. (2004). Sport Tourism and Urban Regeneration. In Sport Tourism: Interrelationships, Impacts and Issues, (B. Ritchie and D. Adair ed.) Clevedon: Channel View Publications. pp.192-205

9. Higham, J., Hinch, T. (2009). Sport and tourism: globalization, mobility and identity.1st ed., Elsevier. Oxford.

10. Hudson S (2003). Sport and Adventure Tourism. The Haworth Hospitality Press, Binghamton, NY, USA.

11. Jovičić, Ž. (1986). Turistička geografija, Naučna knjiga, Beograd.

12. Kesar, O. (2011). Sportski turizam, Zagreb: Internet skripta, Ekonomski Fakultet Sveučilište u Zagrebu.

13. Maksin - Mihić, M. (2008). Turizam i prostor, Univerzitet Singidunum, Fakultet za turistički i hotelijerski menadžment, Beograd.

14. Standeven J, DeKnop P (1999). Sport tourism. Edwards Bros, United States of America.

15. Swartbrooke, J., Beard, C., Leckie, S. \& Pomfret, G. (2003). Adventure tourism: The New Frontier. Oxford, UK: Butterworth-Heinemann

16. http: // www. zoi84.ba/stranica/ski-centar, www.bhtourism.ba/Turist_br26. pdf (14.05.2014). 